\title{
Concomitant thyroid MALT lymphoma and papillary thyroid carcinoma
}

\author{
Concomitância de linfoma MALT de tireoide \\ e carcinoma papilífero de tireoide
}

Giulianno Molina de Melo', Danilo Anunciatto Sguilar', Cyntia Moniz Figueira Petiti', André Gustavo Gumz Eichstaedt', Rogério Ramos Caiado', Ricardo Antenor de Souza e Souza ${ }^{2}$

\section{SUMMARY}

The objective of this study was to describe the rare thyroid MALT Iymphoma concomitant with papillary thyroid carcinoma in a male patient who was submitted to total thyroidectomy. Treatment and follow-up issues are addressed. Male patient complains of fast thyroid enlargement without lymphadenophaty and normal clinical exams. Total thyroidectomy was indicated and performed without any complications. The pathology showed multicentric papillary thyroid carcinoma, concomitant thyroid MALT Iymphoma and Hashimoto's thyroiditis. The immunohistochemistry assay was positive for CD 20, CD 43, CD 79, AE1/AE3. The staging studies showed no evidence of both metastasis, Ann Harbor stage IE, without B symptoms. After RIT no further radiotherapy or chemotherapy was indicated. Nowadays the thyroglobulin is undetectable, without recurrences at two years of follow-up. It was concluded that primary thyroid MALT lymphoma is uncommon being the papillary thyroid carcinoma more frequent. Both occurring concomitantly is very rare and the treatment has to prioritize the tumor of worst prognosis at the discovery moment. Arq Bras Endocrinol Metab. 2010;54(4):425-8

\section{SUMÁRIO}

O objetivo deste trabalho foi descrever um raro linfoma MALT primário de tireoide concomitante com carcinoma papilífero em paciente masculino submetido à tireoidectomia total. $\mathrm{O}$ tratamento e o seguimento são discutidos no texto. Paciente masculino com rápido aumento da tireoide sem linfonodomegalias com exames normais. A tireoidectomia total foi indicada e realizada sem complicações. $\mathrm{O}$ anatomopatológico mostrou carcinoma papilífero multicêntrico concomitante com linfoma MALT e tireoidite de Hashimoto. A imuno-histoquímica foi positiva para $C D$ 20, $C D$ 43, $C D$ 79, AE1/AE3. 0 estadiamento clínico não demonstrou evidência de metástases de ambos, Ann Harbor estádio IE, sem sintomas B. Realizado RIT sem radioterapia ou quimioterapia. Atualmente se encontra com tireoglobulina indetectável, sem recidivas ao seguimento de dois anos. Concluiu-se que o linfoma MALT primário de tireoide é raro e o carcinoma papilífero é o mais frequente com boa evolução. A concomitância de ambos é muito rara e o tratamento deve priorizar a neoplasia que apresenta o pior prognóstico no momento da descoberta. Arq Bras Endocrinol Metab. 2010;54(4):425-8

${ }^{1}$ Clínica e Cirurgia de Cabeça e Pescoço "Jorge Fairbanks Barbosa", Hospital da Beneficência Portuguesa de São Paulo, São Paulo, SP, Brazil

2 Hospital da Beneficência

Portuguesa de São Paulo,

São Paulo, SP, Brazil
Correspondence to: Giulianno Molina de Melo Rua Vergueiro, 266, ap. 171 Bloco Metrópole

01504-000 - São Paulo, SP, Brazil giulianno_molina@hotmail.com

Received on June/11/2009 Accepted on Jan/20/2010
$\mathrm{P}$ rimary thyroid MALT lymphoma is very uncommon, accounting for $0.6 \%$ to $5 \%$ of all thyroid malignancies, with a distinct elderly female predominance and incidence peak between 60 and 69 years. Some authors correlate it to auto-immune diseases like Hashimoto's thyroiditis (1-3). Papillary carcinoma is the most frequent thyroid cancer and responsible by nearly $80 \%$ of all thyroid cancer in the USA, occurring predomi- nately in women (3:1 ratio) in the $3-4$ decade of life (4-6). The concomitance of both is very rare and the present case report has the objective of describe the rare thyroid MALT lymphoma concomitant with papillary thyroid carcinoma in a single old male patient who noted a sudden thyroid enlargement and was submitted to total thyroidectomy. Treatment and follow-up issues are addressed. 


\section{CASE REPORT}

The present case report was previously approved by the Hospital Ethics Committee. A 61 year-old male patient was referred to this service due to fast painless thyroid enlargement during about the last three months without any other complaints. The clinical feature showed a multinodular thyroid enlargement, without neck lymphadenopathy, hoarseness, dysphagia or dyspnea. The thyroid ultrasound showed a $54 \mathrm{~cm}^{3}$ multinodular goiter with some nodules presenting gross calcifications, without other cervical anomaly, laboratory screening showed normal functioning of the thyroid and only serum thyroglobulin antibody was slight increased. The patient was a non-smoker, denied alcohol consumption and has arterial hypertension. Although the preoperative USG guided needle aspirative biopsy is the mainstay in the current literature and should be done in every suspected nodule, we preferred the prompt surgical treatment in this particular case due to the fast multinodular growing in the male patient and the positive history of familial thyroid carcinoma (mother).

Total thyroidectomy was performed without any complications, preserving the inferior and superior laryngeal nerve and the four parathyroids, some technical difficulty occurred due to the extremely hard nodule at the superior left thyroid pole. Discharge was the next day following surgery without complaints until follow-up visits.

The pathology exam showed multicentric papillary thyroid carcinoma, classic variant, without vascular or lymphatic embolization in both lobes, accompanied of Hashimoto's thyroiditis and a concomitant thyroid MALT lymphoma in a nearly $3.5 \mathrm{~cm}$ nodule surrounded by normal thyroid tissue and areas of papillary carcinoma at the left thyroid pole. The immunohistochemistry assay was positive for CD 20, CD 43, CD 79, AEl/AE3 (Figures 1 and 2).

Staging included neck CT, thorax, abdomen and pelvis, PET-CT, total body scintigraphy with MIBI, laboratory evaluation and bone marrow biopsy. All exams showed no evidence of both metastasis so the Ann Harbor (classification for lymphomas modified by Mussoff) staging was stage IE, without systemic B symptoms. Levothyroxine was initiated at $150 \mathrm{mcg}$ per day and the patient was referred to the radioiodine therapy with 150 mCie demonstrating a negative whole body scan. No further radiotherapy or chemotherapy was indicated and nowadays, after two years of follow-up, the patient is stable, with undetectable serum thyroglobulin and without evidence of recurrences.

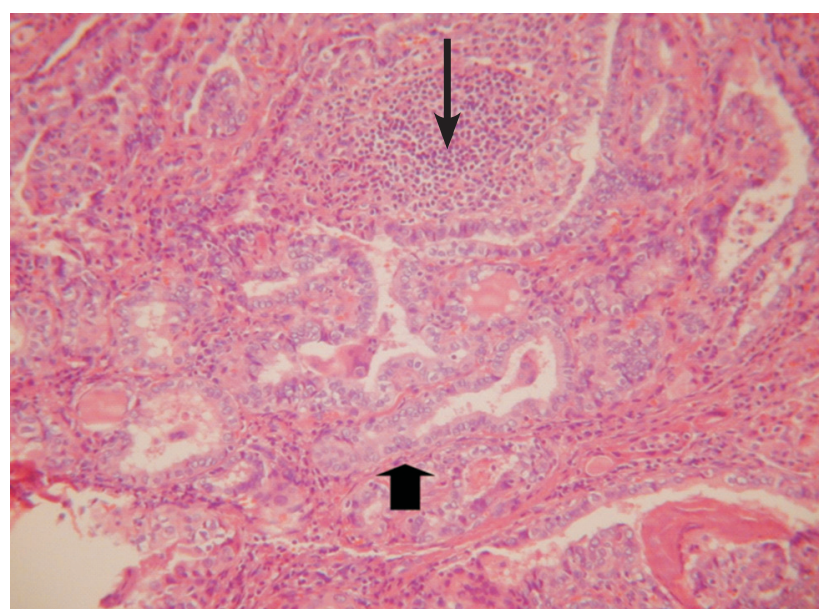

Figure 1. Hematoxycilin-eosin staining showing papillary thyroid carcinoma (thick arrow) concomitantly with MALT thyroid lymphoma (thin arrow).

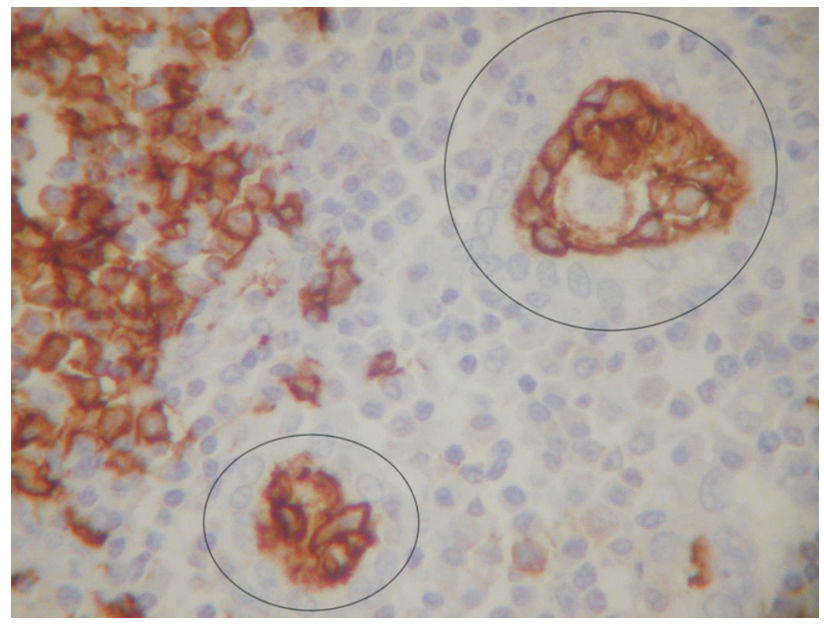

Figure 2. Immunohistochemistry assay showing the CD 20 positivity in MALT lymphoma in thyroid follicules.

\section{DISCUSSION}

Primary thyroid lymphoma is very rare, accounting for $0.6 \%$ to $5 \%$ of all thyroid malignancies, and MALT lymphoma is the most common subtype. It occurs more frequently in the elderly female linked with chronic autoimmune thyroiditis (Hashimoto's disease), being moderate to poor in degree of differentiation. Presentation in the male gender in this report is associated with poor prognosis when compared the WDTC (well differentiated thyroid carcinoma); however, no sufficient data exits regarding MALT lymphoma in literature (7-9).

Differential diagnosis between primary thyroid lymphoma and generalized lymphoma with thyroid involvement must be performed. Clinically the first has the presentation of painless rapid mass growth in the thyroid, sometimes with compressive symptoms which 
can be confused with intracystic hemorrhage or enlargement of a nodule (10). B symptoms like fever, weight loss more than $10 \%$ and nocturnal sweating suggests typical disseminated lymphoma either primary in thyroid gland or in another site. In this report, as other few cases, the disease was discovered only after surgery, once the patient related solely a globus sensation. Preoperative exams such as neck ultrasound, thyroid scintigraphy and even neck CT can be indistinguishable for compressive goiter.

In literature, the majority of MALT lymphomas occur in a previous autoimmune thyroid disease (Hashimoto's thyroiditis), probably due an acquired pathological transformation of the intrathyroid lymphoid tissue. The level of concordance between Hashimoto's disease and MALT lymphoma is $25 \%$ $75 \%$, even though MALT lymphoma occurs in $0.5 \%$ of the cases $(11,12)$. The malignant course is difficult to characterize, attributable to the indolent and long period of time in both clinical and morphological views, as the present case report. Although nearly $40 \%$ of patients present clinical or subclinical hypothyroidism in the primary thyroid lymphoma, this clinical case showed no evidence of laboratory alterations (11).

The present concomitance of MALT thyroid lymphoma and papillary thyroid carcinoma, very rare in the literature, make this case report a challenge in the treatment and follow-up, whose issues must be tailored to each particular case, needing a comprehensive knowledge of both diseases to guide the appropriate medical treatment.

An adequate specimen is necessary for a correct diagnose, which in this report was the entire thyroid gland, although nowadays fine needle aspiration with flow cytometry has been proved useful in some cases (10). The whole tissue was submitted to routine histopathological evaluation, cytomorphologic and immunophenotyping analysis with a panel of monoclonal antibodies: CD 20, CD 43, CD 79, AEl/AE3 and lymphocitic proliferation marker and finally classified with the REAL, the more recent lymphoma classification (12). Indeed, the concomitance of classical multifocal papillary thyroid carcinoma without extracapsular spread with MALT lymphoma was proved.

Treatment options and follow-up of patients with MALT thyroid lymphoma remain controversial at the moment and a correct stage must be determined with complete physical exam, laboratory screening, liver function, bone marrow biopsy, chest, neck, abdomen
CT to ensure optimal treatment. The PET-CT has been presented as the elective exam in the setting of the lymphoma stage, discharge of follow-up and evaluation of clinical response for specific treatment (13). In this report the PET-CT has not evidenced disseminated disease or other primary sites for both thyroid neoplasms. Retrospective reports suggest an indolent behavior and excellent clinical prognosis for this subset of thyroid lymphomas. However, recent published observations in patients with other extranodal MALT-lymphomas have documented the dissemination of disease in about one-third of cases at the time of diagnosis (14). One must prove which tumor is more aggressive in behavior between the papillary thyroid carcinoma and MALT lymphoma to assure the ideal treatment for both.

The Ann Arbor classification for Lymphomas modified by Mussoff was used in this case (15): stage IE disease corresponds to disease confined to the thyroid, stage IIE corresponds to disease confined to the thyroid gland and the regional lymph nodes on the same side of the diaphragm, stage IIIE corresponds to disease confined to the thyroid and lymph nodes on both sides of the diaphragm and/or spleen; and stage IV corresponds to disease in nodal and/or additional extranodal involvement. Localized disease was defined as IE and IIE disease, and disseminated disease as stage IIIE and stage IV.

The present case was staged as IE (localized disease) where single treatment like surgery is evidence-based in the literature (7). However, multimodality (surgery plus radio- or chemotherapy) is still proponed in some institutions with curative intent (16). Radiotherapy, when indicated is performed in total dose of $40 \mathrm{~Gy}$ (10) and multiple chemotherapy (CHOP) is classically indicated for disseminated or locally aggressive lymphoma. Its role in localized disease is not clear (17-19).

The patient who presenting concomitant MALT thyroid lymphoma and papillary thyroid carcinoma must be judiciously evaluated, since the treatment has to prioritize the tumor which presents the worst prognosis at moment. In the present report the staging work-up showed no evidence, at PET-CT and WBS I-131, of disseminated disease for both tumors. Standard treatment with RIT at $150 \mathrm{mCie}$ was then performed for the WDTC while no further treatment was proposed for MALT lymphoma.

Until this date, after trimestrial thyroglobulin, semestrial PET-CT and annual WBS as the standard follow-up from the literature, the patient has not any 
evidence of regional or distance recurrence loci during the two years of follow-up.

Despite the short follow-up of this rare presentation of concomitance of MALT lymphoma and papillary thyroid carcinoma, the patient has not evidenced recurrence. Based on the current literature showing few reports of MALT lymphoma associated to other tumors, this case report has the aim to add the experience of the service in this rare pathology to medical data.

A patient presenting the concomitant MALT thyroid lymphoma and papillary thyroid carcinoma must be judiciously evaluated, since the treatment has to prioritize the tumor with worst prognosis at the moment of discovery. Despite the rarity of thyroid lymphoma, is has to be part of the differential diagnosis when examining the elderly with sudden thyroid enlargement and who have clinical history of Hashimoto's thyroiditis.

Acknowledgments: we would like to thank to Dr. Luis Carlos Sanvitto, Chief, for his endless support and the pathology laboratory team for their effort in preparing the assays.

Disclosure: no potential conflict of interest relevant to this article was reported.

\section{REFERENCES}

1. Lam KY, Chung LY, Kwong DLW, Lee J, Srivastava G. Malignant lymphoma of the thyroid: a 30-year clinicopathological experience and an evaluation of the presence of Epstein-Barr virus. Am J Clin Pathol. 1999;112:263-70.

2. Ansell SM, Grant CS, Habermann TM. Primary thyroid lymphoma. Semin Oncol. 1999;26:316-23.

3. Nakao A, Fukuoka T, Hibi K. Mucosa-associated lymphoid tissue (MALT) lymphoma of the thyroid: report of a case. Anticancer Res. 1999;19(1B):811-4.

4. YamamotoY, MaedaT, Izumi K, et al. Occult papillary carcinoma of the thyroid. A study of 408 autopsy cases. Cancer. 1990;65:1173-9.
5. Correa P, Chen VW. Endocrine gland cancer. Cancer. 1995;75:338-52.

6. DeGroot LJ, Kaplan EL, McCormick M, et al. Natural history, treatment, and course of papillary thyroid carcinoma. J Clin Endocrinol Metab. 1990;71:414-24.

7. Mack LA, Pasieka JL. An evidence-based approach to the treatment of thyroid lymphoma. World J Surg. 2007;31(5):978-86.

8. Cady B, Rossi R. An expanded view of risk-group definition in differentiated thyroid carcinoma. Surgery. 1988;104:947-53.

9. Sebastian SO, Gonzales RJM. Papillary thyroid carcinoma. Prognostic index for survival including the histological variety. Arch Surg. 2000;135:272-7.

10. Earnest LM, Cooper DS, Sciubba JJ, Tufano RP. Thyroid MALT lymphoma in patients with a compressive goiter. Head Neck. 2006;28:765-70.

11. Matsuzuka F, Miyauchi A, Katayama S. Clinical aspects of primary thyroid lymphoma: diagnosis and treatment based on our experience of 119 cases. Thyroid. 1993;3:93-9.

12. Harris N, Jaffe E, Stein H, Banks P, Chan J, Cleary M, Delsol G, et al. A revised European-American classification of lymphoid neoplasms: a proposal from the International Lymphoma Study Group. Blood. 1994;84:1361-92.

13. Wang SA, Rahemtullah A, Faquin WC, Roepke J, Harris NL, Hasserjian RP. Hodgkin's lymphoma of the thyroid: a clinicopathologic study of five cases and review of the literature. Mod Pathol. 2005;18:1577-84.

14. Thieblemont $C$, Mayer A, Dumontet $C$, Barbier $Y$, Callet-Bauchu E, Felman $P$, et al. Primary thyroid lymphoma is a heterogeneous disease. J Clin Endocrinol Metab. 2002;87:105-11.

15. Carbone P, Kaplan H, Musshof K, Smithers D, Tubiana M. Report on the Committee on Hodgkin's disease staging classification. Cancer Res. 1971;31:1860-1.

16. Belal AA, Allam A, Kandil A, El Husseiny G, Khafaga Y, Al Rajhi N, et al. Primary thyroid lymphoma: a retrospective analysis of prognostic factors and treatment outcome for localized intermediate and high grade lymphoma. Am J Clin Oncol. 2001;24:299-305.

17. Vigliotti A, Kong JS, Fuller LM. Thyroid lymphomas stage IE and IIE: comparative results for radiotherapy only, combination chemotherapy only, and multimodality treatment. Int J Radiat Oncol Phys. 1986;12(10):1807-12.

18. Niitsu N, Okamoto M, Nakamura N, Nakamine H, Bessho M, Hirano M. Clinicopathologic correlations of stage IE/IIE primary thyroid diffuse large B-cell lymphoma. Ann Oncol. 2007;18(7):1203-8.

19. Brepoels L, Stroobants S. PET scanning and prognosis in Hodgkin's lymphoma. Curr Opin Oncol. 2008;20(5):509-16. 